\title{
Investigation of the changes in texture of soybean sprout depending on the heating conditions in sous-vide and conventional hot water cooking
}

\author{
Yun Ju Lee ${ }^{1} \cdot$ Hwabin Jung ${ }^{1}$ Won Byong Yoon ${ }^{1}$
}

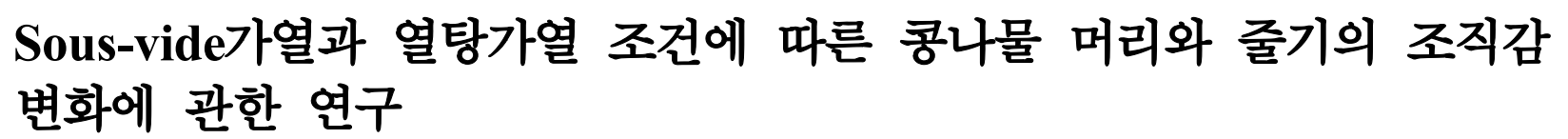

이윤주 ${ }^{1}$ - 정화빈 ${ }^{1}$ - 윤원병 ${ }^{1}$

Received: 28 May 2018 / Accepted: 28 June 2018 / Published Online: 30 September 2018

(C) The Korean Society for Applied Biological Chemistry 2018

\begin{abstract}
The purpose of this study was to investigate the effect of thermal treatments, such as a sous-vide and a conventional hot water cooking, on the texture changes of soybean sprout. A novel method to measure texture properties of soybean sprout have been determined because of the irregular geometry of soybean sprout. The shape of cotyledon of bean spout was accurately analyzed using an image processing and a geometry model. To minimize the effect of the contact area on the texture measurement, a blade type of probe was selected for the measurement. True stress was evaluated to reflect the shape changes during deformation, and demonstrated that the measurement accurately distinguished the effect of thermal treatment on the texture. Different heating time (i.e., 0, 10, 20, and $30 \mathrm{~min}$ ) was applied for both sous-vide and conventional cooking. Thermal processing caused hardening of textures for both cotyledon and hypocotyl of soybean sprout. The conventional cooking method showed higher stress values than those of sous-vide cooking. Sprouts cooked by sous-vide released the moisture after thermal processing while sprout cooked by a conventional water bath method could hold the moisture content
\end{abstract}

Won Byong Yoon $(\varangle)$

E-mail: wbyoon@kangwon.ac.kr

${ }^{1}$ Department of Food Science and Biotechnology, Kangwon National University, Kangwondaehak-gil, Chuncheon, Gangwon 24341, Republic of Korea

This is an Open Access article distributed under the terms of the Creative Commons Attribution Non-Commercial License (http://creativecommons. org/licenses/by-nc/3.0/) which permits unrestricted non-commercial use, distribution, and reproduction in any medium, provided the original work is properly cited. during thermal processing. The soybean sprouts treated by conventional cooking method showed a higher score in sensory evaluation.

Keywords Conventional cooking ' Hardness - Soybean sprout · Sous-vide $\cdot$ True stress

\section{서 론}

콩을 이용한 가공식품인 두부, 된장, 콩나물 등은 골다공증, 심 장병, 유방암 등에 효과가 있다는 연구결과에 따라 콩 발아식 품에 대한 소비자들의 관심 및 수요가 증가하고 있다[1]. 콩나 물(Glycine $\max$ (L.) Merr.)은 불린 콩을 광선을 쬐지 않고 일 정 시간 발아시킨 채소로서 한국 고유의 전통식품이며, 사시사 철 수확이 가능하여 비교적 저렴하게 구입할 수 있다. 콩나물 은 고려시대 일상생활에서 이전부터 이용되어 온 보편적인 농 산물로서 채소 공급이 힘들었던 겨울철에 thiamin, ascorbic acid, carotene등의 비타민, 단백질, 식이섬유의 주요 공급원 역 할을 해왔다[1]. 콩이 발아하여 콩나물이 되면서 lutein, $\beta$ carotene, 엽록소 $\alpha$ 는 감소하지만, 원료인 콩에 비해 isoflavone과 asparagine의 함량이 높아 소화율과 숙취해소에 효과가 있는 이 로운 영양식품이다[2,3].

현대인의 바쁜 생활 및 편리함 추구, 1 인가구의 증가에 따라 조리식품, 반조리식품 등 Ready-to-eat (RTE), Ready-to-cook (RTC), 가정 간편식(Home meal replacement, HMR)이 증가하 고 있다. 현대인들은 RTE, RTC, HMR을 주로 대형 할인점, 동 네 중소형 슈퍼마켓, 편의점 등을 통해 구입하며, 콩나물은 주 
로 국, 찌개, 밥 등에 포함되어 간편식의 식자재로서 이용되고 있다[4]. 이에 따라 식자재로서의 콩나물의 수요도 증가하고 있 다. 더불어 소비자들의 가공식품에 대한 관심이 높아짐에 따라 가공식품에 대한 종류 및 품질향상이 요구되고 있다.

간편식은 저장기간을 확보하기 위하여 냉장, 냉동, 상온 유통 한다. 간편식에 이용되는 콩나물을 포함한 모든 식자재들은 산 업에서 건조 공정, 가열 공정 또는 냉각 공정에 의한 열의 이 동에 따라 내부 고형분의 물리화학적 특성이 변화한다. 고온 가 열처리 시 식품의 품질이 변화하며, 특히 열에 약한 채소의 품 질은 더욱 낮아지므로 가열처리식품의 품질변화를 최소화하는 가열살균 방법에 대한 연구가 보고되고 있다[5,6,7].

콩나물은 채소의 한 종류이므로 가열 방법에 따라 조직감이 상이하다. 소비자의 기호도에 맞는 콩나물 조리 식품을 생산 하 기 위하여 조리 후 맛, 향, 품질 특성 변화와 같은 관능적 평 가가 중요하다[8]. 따라서 소비자들의 간편식품에 대한 품질평 가를 확인하기 위하여 간편식품의 재료인 콩나물의 가열 후 조 직감의 변화에 대한 연구가 필요하다. 조직감 측정 시, 콩나물 의 형상은 자엽과 배축으로 이루어져 있고 콩나물의 자엽은 콩 나물 마다 형상이 상이하므로 변형 시 프로브의 종류에 따라 접촉하는 면적이 변화하여 값이 다르다는 문제가 있다. 따라서 변화하는 면적을 반영한 정확한 조직감 측정방법이 필요하다.

따라서 본 연구에서는 가열처리 과정이 콩나물의 조직감 변 화에 미치는 영향을 기기적인 측정법으로 정량화하는 것을 목 적으로 하고 있으며, 이를 위하여 부정형의 형상을 지닌 콩나 물의 자엽과 배축의 조직감을 정교하게 측정하는 방법을 도출 하고자 하였다.

\section{재료 및 방법}

\section{실험재료}

실험에 사용한 콩나물(CJ제일제당(주), Seoul, Korea)은 춘천 소 재의 마트에서 구입하여 $6{ }^{\circ} \mathrm{C}\left( \pm 1{ }^{\circ} \mathrm{C}\right)$ 의 냉장고에 냉장 보관하 였으며, 구입일로부터 5일 이내에 사용하였다. 이후 반복 실험 을 위하여 지속적으로 동일한 콩나물 제품을 구매하여 동일한 방법으로 보관하며 실험에 사용하였다.

\section{영상분석}

콩나물의 자엽 형상 이미지를 획득하기 위하여 영상분석장치 (RM-PB4040, RAMI, Seoul, Korea)와 카메라(EOS 500D, Canon, Tokyo, Japan)를 이용하였다. 영상분석장치 중앙에 한 쌍의 자엽의 경계를 기준으로 절단하여 위치시켰다. 카메라를 영상분석 장치로부터 $5 \mathrm{~cm}$ 수평으로 거리를 두어 콩나물 측면 의 이미지를 획득 하였으며, 영상분석장치로부터 $9 \mathrm{~cm}$ 수직으 로 거리를 두어 콩나물 윗면의 이미지를 획득하였다. 두 가지 측면에서 촬영한 이미지를 이용하여 콩나물 자엽의 장축과 단 축의 길이 그리고 측면에서의 높이를 구하기 위하여 MATLAB (Version 8.5, The MathWorks, Inc., Natick, MA, USA) 소프 트웨어를 이용하였다. 영상분석을 통하여 획득한 장축, 단축, 높 이를 통하여 콩나물의 단면적과 부피는 다음과 같이 구하였다.

$$
\begin{aligned}
& S=\sum_{i=1, j=1}^{\text {size }} \pi a_{i} b_{j} \alpha \\
& V=\sum_{i=1, j=1, k=1}^{\text {size }} \frac{4}{3} \pi a_{i} b_{j} c_{k} \alpha
\end{aligned}
$$

$S$ 는 단면적을 의미하며 $V$ 는 부피, $a i, b j, c k$ 는 각각 장축의 반 지름, 단축의 반지름, 높이에 해당하며 1 pixel을 간격으로 $x$ 축 을 따라 이동하였으며, $\alpha$ 는 pixel 단위를 $\mathrm{mm}$ 단위로 보정하기 위한 단위환산 인자로 실험을 통해 얻은 값인 0.0203 이 입력되 었다.

\section{조직감 측정}

콩나물의 조직감 측정은 texture analyzer (CT3, Brookfield, Stoughton, MA, U.S.)를 사용하여 경도를 측정하였다. 한 쌍의 자엽의 경계를 기준으로 절단된 자엽의 반쪽만을 측정 시료로 사용하였으며, 콩나물의 배축은 콩나물 자엽을 제거 후 측정 시 료로 사용하였다. Texture analyzer에 프로브로서 실린더형 프로 브 TA5 (직경 $12.7 \mathrm{~mm}$ )와 칼날형 프로브 TA7을 이용하여 10 회 반복 측정 하였다. 측정 시 기기의 조건은 콩나물 자엽의 경 우 deformation $30 \%$, 콩나물 배축의 경우 $99.9 \%$ 로 하였으며, 이후 test speed는 $0.50 \mathrm{~mm} / \mathrm{s}$, trigger load는 $7 \mathrm{~g}$ 으로 동일하게 설정하였다.

\section{면적의 계산}

본 연구에서는 콩나물의 조직감을 hardness와 true stress로서 비 교하고자 하였다. 조직감 측정 시 샘플의 면적이 필요하므로 true stress로서 조직감을 확인하기 위하여 콩나물 자엽이 texture analyzer의 프로브에 의해 $30 \%$ deformation이 되었을 때의 면 을 측정하였다. $30 \%$ deformation 시 실린더형 프로브와 샘플이 접촉하는 면적을 윗면에서 보았을 때 Fig. $1 \mathrm{~A}$ 와 같으며, 칼날 형 프로브와 샘플이 접촉하는 면적을 윗면에서 보았을 때는 Fig. $1 \mathrm{~B}$ 와 같다. Fig. 1 에서 실선은 콩나물 자엽의 면적을 나타낸 것 이며, 점선은 프로브를 나타낸 것이다. 칼날형 프로브가 샘플과 접촉하는 두께는 $0.88 \mathrm{~mm}$ 이며, $30 \%$ deformation시 샘플과 프 로브가 접촉하는 면적을 고려한 true stress는 다음과 같이 구하 였다.

True stress by cylinder probe $\left(\mathrm{g} / \mathrm{mm}^{2}\right)=$

$$
\operatorname{hardness}\left(\pi \times \sqrt{a^{2}-\frac{a^{2}}{b^{2}} y^{2}} \times \sqrt{c^{2}-\frac{a^{2}}{b^{2}} y^{2}}\right)
$$

True stress by blade probe $\left(\mathrm{g} / \mathrm{mm}^{2}\right)=$

$$
\operatorname{hardness}\left(0.88 \times \sqrt{\alpha^{2}-\frac{a^{2}}{b^{2}} y^{2}}\right)
$$

$\mathrm{a}$ 와 $\mathrm{c}$ 는 각각 타원의 장축과 단축의 반지름이며, $\mathrm{b}$ 는 콩나물의 높이다. 실제 콩나물의 장축과 단축의 수치는 버니어 캘리퍼스 (BLUEBIRD, HongKong, China)를 통하여 측정하였으며, 높이 는 texture analyzer 기기를 통해 측정된 값을 사용하였다. 콩나 물의 배축은 조직감을 측정하고자 하는 부위의 두께를 버니어 


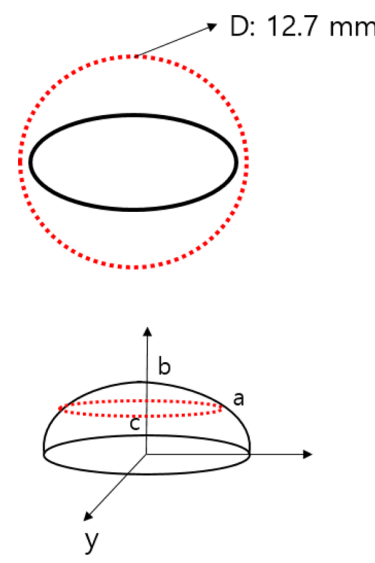

(A)
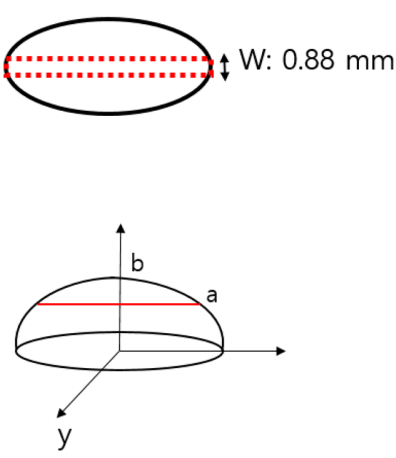

(B)

Fig. 1 The contact area of texture analyzer probe and samples

캘리퍼스를 이용하여 측정하였다. 측정 및 기기를 통해 얻은 값 을 식 (3)과 식 (4)를 이용하여 하여 $30 \%$ deformation시 접촉 하는 면적을 구하였다.

Major axis of area by $30 \%$ deformation:

$$
x=\sqrt{a^{2}\left(1-\frac{y^{2}}{b^{2}}\right)}
$$

Minor axis of area by $30 \%$ deformation:

$$
x=\sqrt{c^{2}\left(1-\frac{y^{2}}{b^{2}}\right)}
$$

위 식에서 $\mathrm{x}$ 는 $30 \%$ deformation시에 해당하는 콩나물 자엽의 장축이며, $\mathrm{y}$ 는 조직감 기기를 통해 측정된 콩나물 높이를 기준 으로 $30 \%$ deformation시에 해당하는 높이이다.

\section{수분함량}

수분함량은 $105{ }^{\circ} \mathrm{C}$ 상압가열 건조법으로 A.O.A.C. 표준시험법 에 의하여 3 회 반복 측정하여 그 평균값을 구하였다.

\section{가열처리 방법}

가열처리 방법에 따른 콩나물의 조직감을 비교하기 위하여 처리 를 하지 않은 생 콩나물(raw)을 대조군으로 하였다. Conventional cooking은 $12 \times 14 \mathrm{~cm}$ 크기의 레토르트 파우치(NY15 LLDPE70) 에 생 콩나물 $10 \mathrm{~g}$ 과 $84{ }^{\circ} \mathrm{C}$ 의 물 $90 \mathrm{~mL}$ 을 넣고 포장한 것을 $84{ }^{\circ} \mathrm{C}$ 의 항온수조(BW-05G, JEIO TECH, Daejeon, Korea)에서 $20 \mathrm{~min}$ 간 처리하였다. Sous-vide는 동일한 레토르트 파우치에 생 콩나물 $10 \mathrm{~g}$ 을 넣고 진공포장 한 후 $84^{\circ} \mathrm{C}$ 의 항온수조에서 $20 \mathrm{~min}$ 간 처리하였다. 가열처리 후 시료는 수돗물에 $5 \mathrm{~min}$ 간 냉각하 였다.

\section{쿵나물 자엽의 미세구조 관찰}

동결건조한 생 콩나물과 conventional cooking 처리한 콩나물의 미세구조 관찰을 위하여 납/백금으로 코팅한 후 전계방사형 주

사전자현미경(Hitachi S-4300, Hitachi Ltd., Tokyo, Japan)을 사용하여 $1.0 \mathrm{kV}$ 에서 500 배율로 관찰하였다.

\section{관능검사}

강원대학교 식품생명공학과 재학생 10 명에게 실험목적을 설명 하고 7점 척도법을 이용하여 관능검사를 하였다. $20 \mathrm{~min}$ 간의 conventional cooking 가열처리한 콩나물과 sous-vide 가열처리 한 콩나물에 대해 맛, 색, 향, 조직감, 전체적인 기호도에 대해 조사하였다. 맛은 고소한 콩나물의 맛이 강할수록, 자엽의 색은 노란색이 진할수록, 배축의 색은 더 하얄수록, 향은 콩나물의 고소한 향이 진할수록, 조직감은 단단할수록, 기호도는 높을수 록 높은 점수를 부여하도록 하였다.

\section{통계분석}

실험 결과는 SPSS 통계프로그램(version 23.0, SPSS Institute Inc., Chicago, IL, USA)을 사용하여 평균과 표준편차를 구하였 으며, 결과의 차이를 분산분석(ANOVA)을 통하여 $p<0.05$ 수준 에서 Duncan's multiple range test로 시료 간 유의성을 검정 하였다.

\section{결과 및 고찰}

\section{영상분석을 통한 콩나물 형상 확인}

콩나물은 컨트롤 박스에서 정적인 상태로 획득하여 배경을 제 어하였으므로 콩나물의 관심영역을 추출하기 위해서 이진화된 콩나물 이미지의 콩나물 부분만을 잘라내었다. 이에 대한 결과 를 Fig. 2에 나타내었으며 원본 이미지(Fig. 2A)와 관심영역 이 미지(Fig. 2B), 관심영역을 binary로 추출한 이미지(Fig. 2C)을 나타낸다. Fig. 2 C에서 콩나물을 윗면에서 촬영한 이미지의 관 심영역 행은 pixel이 가장 많은 행에 해당하는 pixel을 계수하 여 장축의 길이를 확인하였으며, 단축은 Fig. 2 C에서 콩나물을 윗면에서 촬영한 이미지를 $-90^{\circ}$ 방향으로 회전하여 동일한 방 법으로 구하였다. 콩나물의 높이는 Fig. $2 \mathrm{C}$ 에서 콩나물을 측면 에서 촬영한 이미지를 $-90^{\circ}$ 방향으로 회전하여 동일한 방법으

(A)
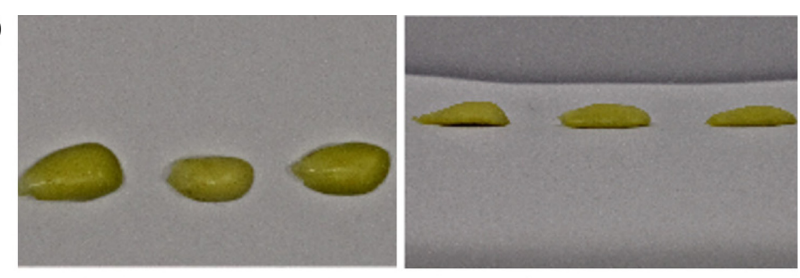

(B)

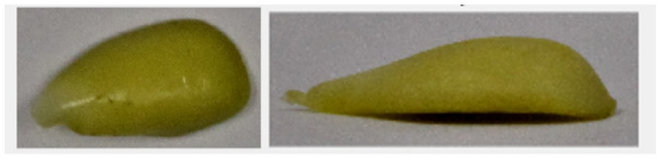

(C)

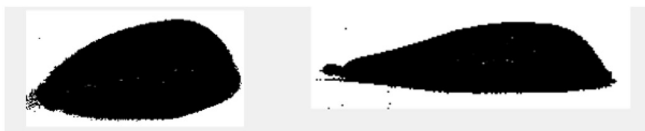

Fig. 2 Captured image of the top and side view (A), the region of interest (B), the region of interest by binary 


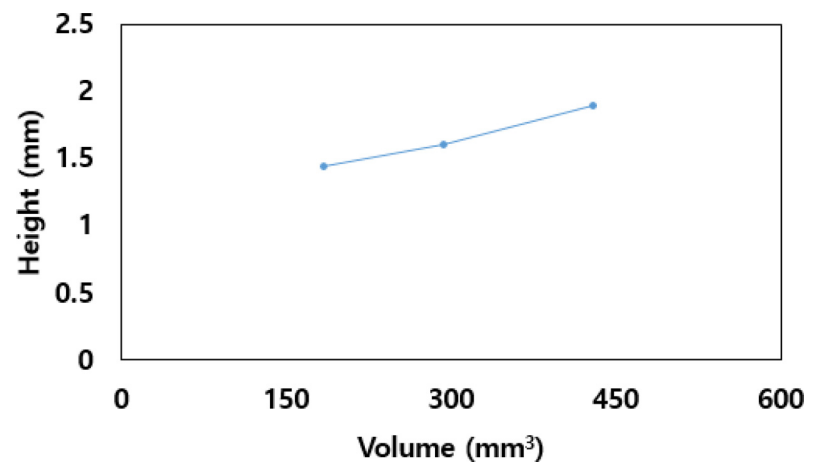

Fig. 3 The relationship between cross section and volume

로 구하였다. 영상분석을 통해 얻은 콩나물의 단면적은 $148.29 \pm$ $18.47 \mathrm{~mm}^{2}$ 이었으며, 부피는 $302.21 \pm 123.20 \mathrm{~mm}^{3}$ 이었다. 콩나물 의 높이가 증가할수록 부피도 증가했으며, Fig. 3를 통하여 콩 나물의 형상은 콩나물 마다 높이가 상이하며 체적에 의한 차이 가 큰 것을 확인하였다. 수화 시 건해삼에 대한 연구에서 건해 삼의 두께와 단면적에 따라 체적이 상이 하였다[9].

\section{콩나물의 조직감 측정방법}

콩나물 자엽의 축에 따른 조직감 변화를 비교하기 위하여 생 콩나물의 장축과 단축 방향으로 콩나물의 true stress를 측정한 결과는 Fig. 4에 나타내었다. Texture analyzer의 칼날형 프로브 를 기준으로 칼날형 프로브와 콩나물 자엽의 장축이 수평을 이 루도록 콩나물 자엽을 위치시키고 조직감을 측정한 것이 major axis이며, 칼날형 프로브와 콩나물 자엽의 단축이 수직을 이루 도록 콩나물 자엽을 위치시키고 조직감을 측정한 것을 minor axis로 하였다. Minor axis의 true stress는 $45.53 \pm 11.41 \mathrm{~g} / \mathrm{mm}^{2}$ 이며, major axis의 true stress는 $43.45 \pm 6.66 \mathrm{~g} / \mathrm{mm}^{2}$ 로 축 방향 에 따른 조직감 측정 값에 유의미한 차이가 없었다. 콩나물 자 엽은 장축을 기준으로 조직감을 측정하는 것이 단축을 기준으 로 측정하는 것보다 편차가 작으므로 콩나물 자엽의 조직감 측 정은 장축을 기준으로 측정하는 것이 품질에 따른 유의적인 조 직감 차이를 확인하기에 적합한 방법임을 확인하였다. 이와 유 사하게 일반 게맛살은 가로, 세로, 대각선의 결 방향에 따라 조 직감에 영향을 받는다는 연구결과를 보고하였다[10].

식품의 시료들은 모형이 일정하지 않은 경우가 많으며, 조직 감 측정 시 프로브와 샘플이 접촉하는 면적이 일정하지 않으면

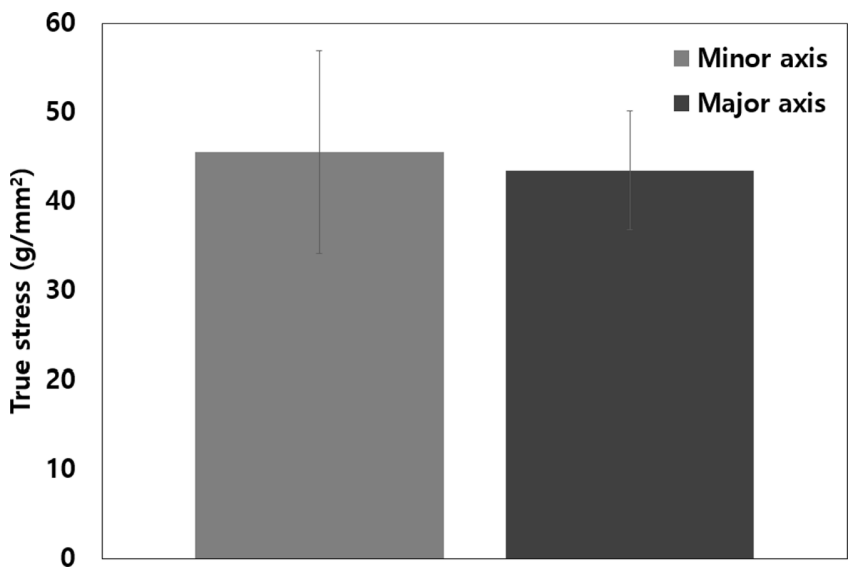

Fig. 4 True stress of cotyledon of soybean sprout by axis

조직감 측정 편차가 크기 때문에 모형이 일정하지 않은 시료는 조직감 측정을 위하여 일정한 모형으로 절단하여 시료로 사용 한다. 일정하지 않은 두께를 가진 감자, 고구마, 당근, 호박의 경도 측정시 사각썰기와 채썰기를 통하여 동일한 모형으로 조 직감을 측정하였다[11]. 콩나물 자엽의 경우 조직감 측정 시 프 로브와 시료가 접촉하는 면적이 굴곡지므로 프로브의 모형과 동 일한 모형으로 시료를 절단하여 사용해야 조직감 편차가 낮지 만, 콩나물 자엽의 경우 크기가 작아 조직감 측에 적합한 크기 로 절단하는 것이 어렵다. 이에 따라 콩나물 자엽의 조직감 측 정법에 따라 조직감 측정 값에 미치는 영향을 분석하기 위하여 콩나물 자엽 면적의 고려 유무에 따른 조직감 특성에 대한 연 구를 진행하였다. 콩나물 자엽의 조직감 측정 시 프로브와 접 촉하는 콩나물 자엽의 면적을 고려하지 않은 hardness는 Fig. $5 \mathrm{~A}$ 를 통해 확인할 수 있었으며 면적을 고려한 true stress는 Fig. $5 \mathrm{~B}$ 를 통하여 확인할 수 있었다. 면적을 고려하지 않은 콩 나물 자엽의 조직감을 실린더형 프로브와 칼날형 프로브로 측 정하였을 때 각각 $2214.55 \pm 304.90,341.36 \pm 44.05 \mathrm{~g}$ 이었으며, 프 로브 종류에 따라 유의미한 차이가 있었으나, 실린더형과 칼날 형 프로브에 따른 면적을 고려한 콩나물 자엽의 조직감은 40.52 $\pm 5.08,35.78 \pm 6.76 \mathrm{~g} / \mathrm{mm}^{2}$ 로 유의미한 차이가 없었다. 콩나물 자 엽의 조직감을 측정하는데 있어 자엽의 모형이 일정하지 않기 때문에 프로브와 닿는 면적을 고려해주지 않으면 측정 프로브 인 실린더형과 칼날형 프로브 종류에 따라 가열처리 방법에 따 른 조직감 측정 시 측정 값을 유의미하게 식별할 수 없다. 이
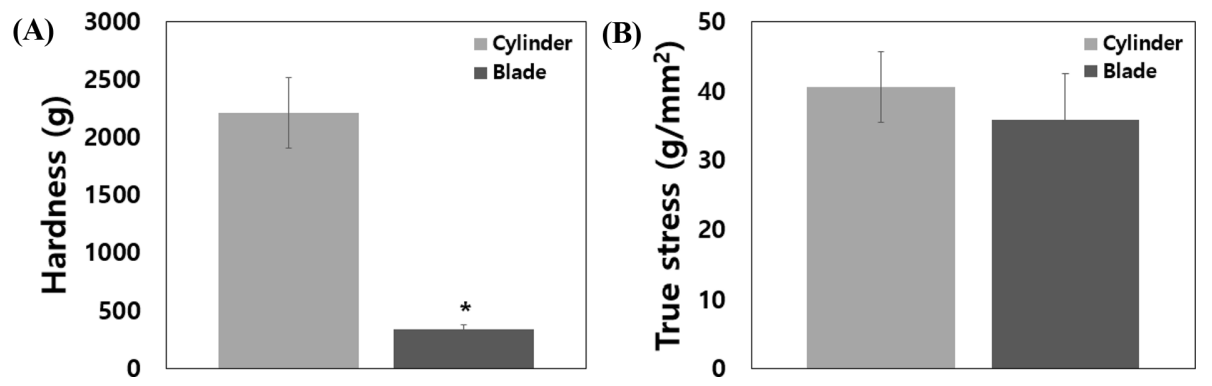

Fig. 5 Hardness (A) and true stress (B) of cotyledon of soybean sprout 
Table 1 Moisture ratio of cotyledon and hypocotyl of soybean sprout

\begin{tabular}{lcc}
\hline \hline \multirow{2}{*}{ Samples } & \multicolumn{2}{c}{ Moisture content $(\%)$} \\
\cline { 2 - 3 } & Cotyledon & Hypocotyl \\
\hline Raw & $74.12 \% \pm 0.92^{\mathrm{a}}$ & $95.61 \% \pm 0.19^{\mathrm{a}}$ \\
Conventional cooking & $78.49 \% \pm 0.29^{\mathrm{b}}$ & $97.63 \% \pm 0.01^{\mathrm{b}}$ \\
Sous-vide & $73.53 \% \pm 0.67^{\mathrm{a}}$ & $94.74 \% \pm 0.41^{\mathrm{c}}$ \\
\hline
\end{tabular}

${ }^{\mathrm{a}-\mathrm{c}}$ Value with different superscripts within a column are significantly different at $p<0.05$

와 같은 현상으로 조직감 측정 시 크기가 일정치 않은 콩나물 을 true stress로서 조직감을 확인해야 할 것으로 판단된다.

\section{가열처리 방법에 따른 콩나물 조직감 측정}

생 콩나물과 conventional cooking 가열처리한 콩나물, sousvide 가열처리한 콩나물의 조직감을 분석하였으며, 가열처리 방 법에 따른 콩나물 자엽과 배축의 수분함량은 Table 1에 나타냈 다. 채소류와 과일류는 가열처리 시 세포막의 단백질이 변성되 어 수분의 이동이 용이하다는 연구결과에 따르면[12], 본 연구 에서 conventional cooking 가열처리한 콩나물의 부피가 sousvide 가열처리한 콩나물의 부피보다 큰 것은 콩나물 내부의 수 분함량 차이로 인하여 외부 수분이 콩나물 자엽과 배축으로 이 동하여 수분함량 증가에 따른 부피 증가로 사료된다. Sous-vide 가열처리한 콩나물은 진공상태이므로 수분의 이동이 없으므로 콩나물 자엽의 수분함량은 생 콩나물과 유의미한 차이가 없었 으며 부피의 변화가 나타나지 않았다. 가열처리 방법에 따라 수
분 함량의 차이가 있는 콩나물 자엽의 조직감은 Fig. 6에 배축 의 조직감은 Fig. 7에 나타내었다. 조직감 측정 기기의 실린더 형 프로브와 접촉하는 면적을 고려하지 않은 콩나물 자엽과 배 축의 hardness는 가열처리 방법에 따라 유의미한 차이가 없으 며, 블레이드형 프로브와 닿은 면적을 고려하지 않은 콩나물 자 엽의 hardness는 생 콩나물과 conventional cooking 가열 시 조 직감 값에는 유의미한 차이가 있었으나 생 콩나물과 sous-vide 가열 시 조직감 값에는 유의미한 차이가 없었다. 반면, 콩나물 배축을 블레이드형 프로브로 측정한 후 프로브와 샘플이 접촉 하는 면적을 고려하지 않은 hardness에서는 raw, conventional cooking, sous-vide 가열처리 방법에 따라 각각 $405 \pm 45.58$, $785.83 \pm 113.55,474.62 \pm 74.73 \mathrm{~g}$ 로 유의미한 차이를 보였으며, 면 적을 고려한 true stress도 가열처리 방법에 따라 유의미한 조직 감 차이를 확인하였다. 실린더 프로브와 접촉하는 면적을 고려 한 콩나물 자엽의 true stress는 가열방법에 따라 유의미한 차이 가 없었으나 칼날형 프로브를 사용한 경우에는 raw, conventional

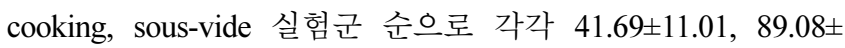
$10.03,68.16 \pm 5.93 \mathrm{~g} / \mathrm{mm}^{2}$ 로 유의미한 차이를 보였다. 가열처리 방법에 따라 실린더형 프로브와 접촉하는 면적을 고려한 콩나 물 배축의 조직감 측정 시 유의미한 차이가 없었으나 블레이드 형 프로브를 이용하여 면적을 고려한 조직감 측정 시 가열처리 에 따른 raw, conventional cooking, sous-vide는 각각 193.08 \pm $34.32,396.70 \pm 60.65,284.69 \pm 39.86 \mathrm{~g} / \mathrm{mm}^{2}$ 로 유의미한 차이를 보였다. 이와 같은 측정 결과를 통하여 가열처리 방법에 따라 변화하는 콩나물 자엽과 배축의 조직감은 콩나물의 모형이 일 정하지 않기 때문에 실린더형 프로브를 이용하여 deformation시
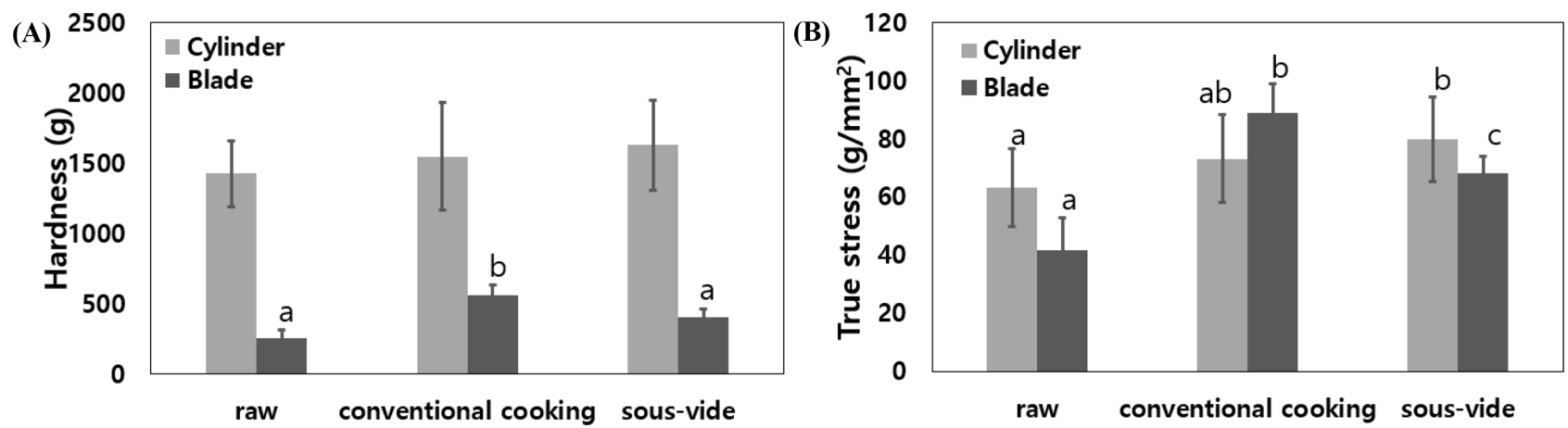

Fig. 6 Hardness (A) and true stress (B) of cotyledon of soybean sprout according to the heating methods
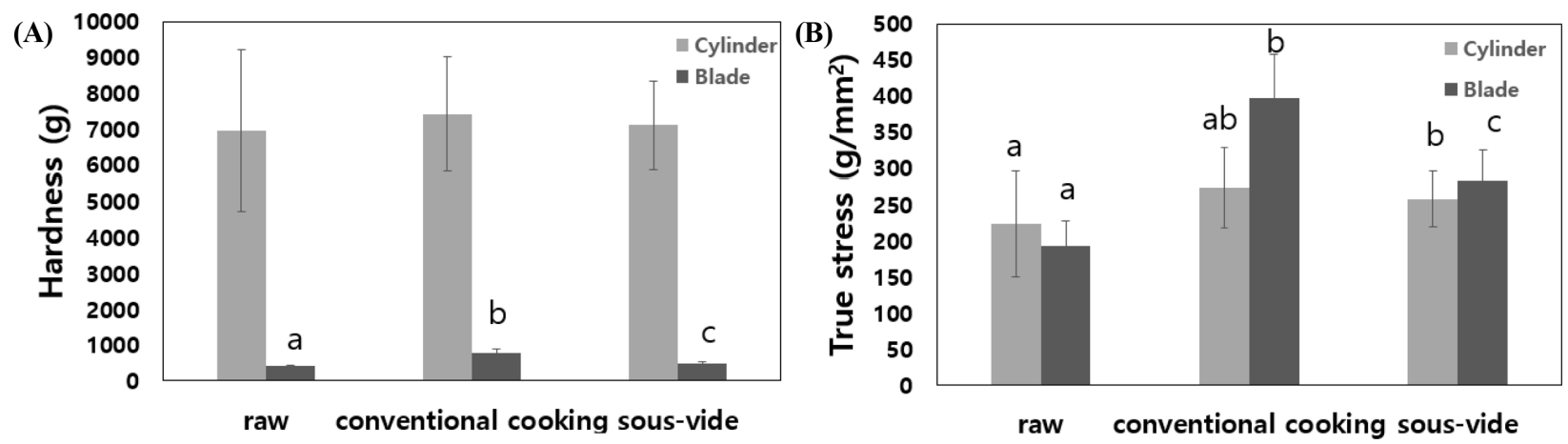

Fig. 7 Hardness (A) and true stress (B) of hypocotyl of soybean sprout according to the heating methods 

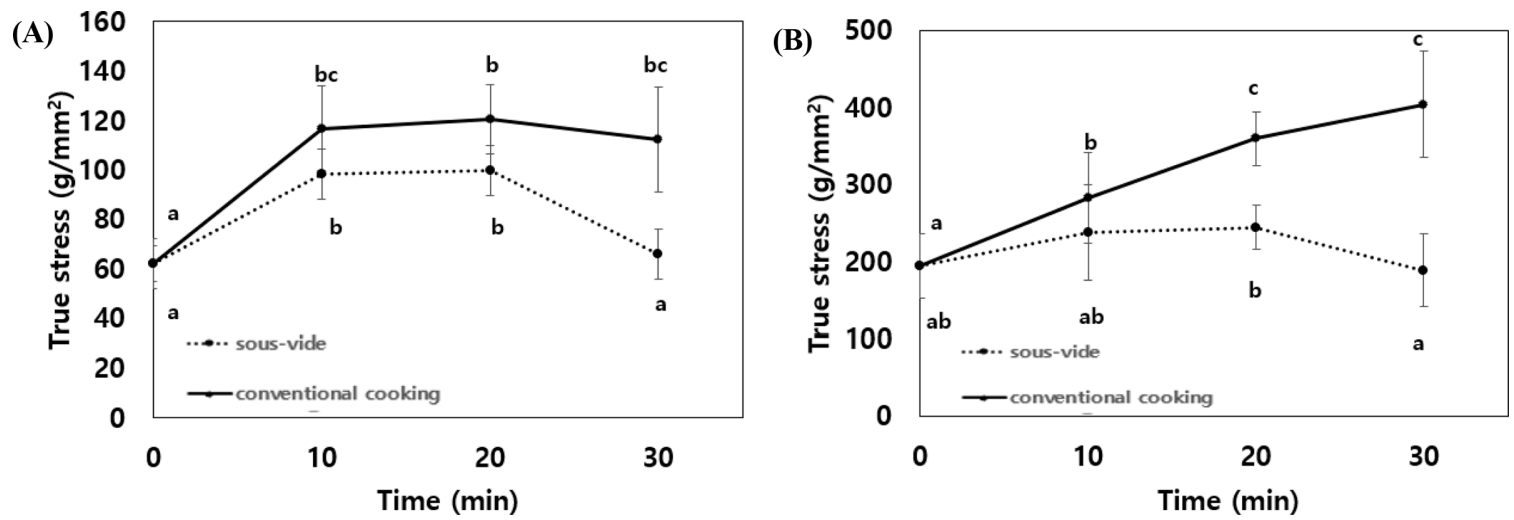

Fig. 8 True stress of cotyledon (A) and hypocotyl (B) of soybean sprout according to the heating times

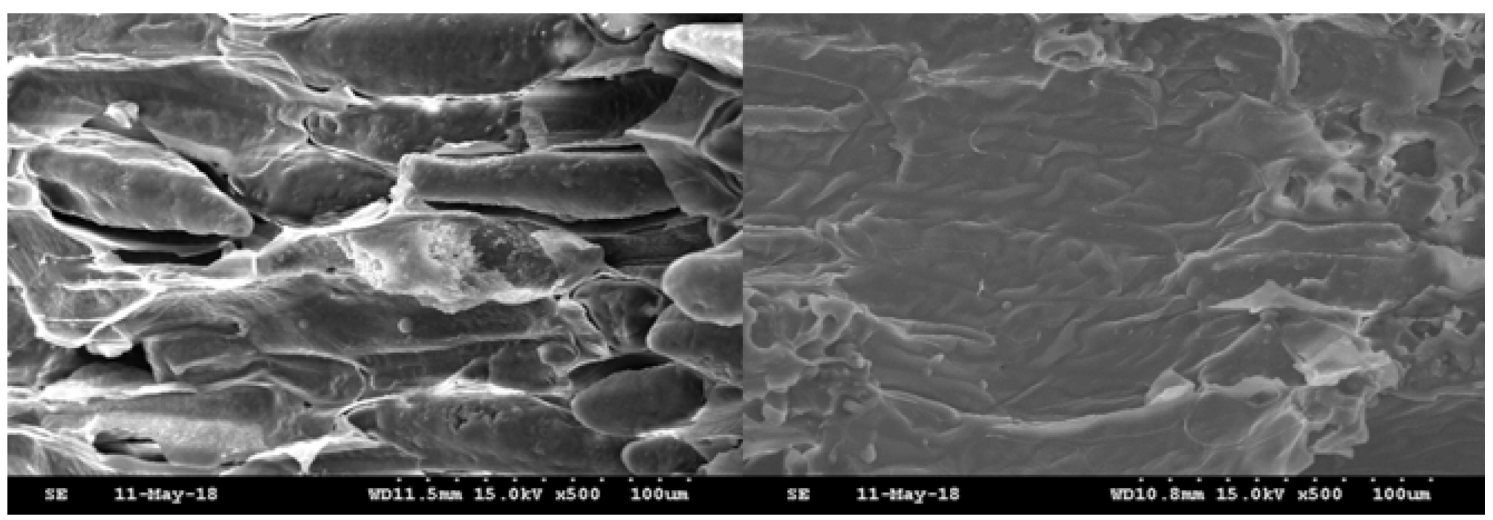

Fig. 9 FE-SEM images of cotyledon of soybean sprout at different heating method (magnification: $\times 500)$

에 변화하는 면적에 의한 조직감 측정보다 칼날형 프로브를 이 용하여 deformation시 프로브와 샘플이 닿는 면적이 일정한 조 직감 측정 시 가열처리 방법에 따른 조직감의 변화를 유의미하 게 확인할 수 있다. 콩나물의 자엽과 배축의 경도는 conventional cooking 가열처리한 것이 sous-vide 가열처리한 것보다 높았다. 이와 같은 경향은 sous-vide 가열처리한 콩나물의 자엽과 배축 에는 starch가 함유되어 있어 conventional cooking 가열처리한 실험군이 수분함량 증가와 열에 의한 호화작용으로 sous-vide 가열처리 한 실험군 보다 경도가 높았다[13]. 브로콜리와 콜리 플라워의 경우에도 boiling과 sous-vide 방법으로 가열처리했을 때 boiling가열처리로부터 얻은 수분과 브로콜리와 콜리플라워 자체에 존재하는 starch로 인하여[14,15] 전분의 호화에 의한 경 도가 증가한 결과를 나타내었다[16]. Sous-vide 가열처리한 콩 나물은 생 콩나물과 비교하였을 시 부피와 밀도의 변화가 없었 으나 내부의 구조가 변화하여 생 콩나물 보다 높은 경도 값을 나타내었다. 콩나물과 같은 채소류의 가열처리 후 조직감의 변 화는 채소류에 함유된 셀룰로오스, 헤미셀룰로오스, 펙틴, 리그 닌과 같은 식이섬유에 의한 것이라 보고된 바 있다[17]. Sousvide 가열처리한 콩나물의 경도 증가는 펙틴에 의한 경도로 사 료된다. 채소류에 함유된 펙틴 가열 시 콩나물이 함유하고 있 는 칼슘과 펙틴이 가교결합뿐만 아니라 펙틴 분자끼리 새로운 결합을 형성함에 따른 조직감 증가이며, 새로운 결합은 열에 의 하여 깨지지 않는다[18,19]. Boiling과sous-vide 가열방법으로 브
로콜리와 콜리플라워를 가열 시 boiling 가열처리 한 것이 수분 함량 높으며 단단한 정도가 더 높은 것을 확인하였다[16].

\section{가열시간에 따른 콩나물 조직감 측정}

생 콩나물, conventional cooking, sous-vide 가열처리 방법으로 하여 가열 시간 10 분 간격에 따른 콩나물의 조직감을 Fig. 8 에 나타내었다. Conventional cooking 가열처리에 따른 콩나물의 자 엽의 조직감은 초기 가열시간 0 분과 10 분 시 유의미한 차이가 있었으나, 가열시간 10 분 이후부터는 true stress의 유의미한 차 이를 보이지 않았다. 가열 초기 자엽의 true stress가 증가한 이 유는 앞에서 언급했듯이 가열에 따른 펙틴의 구조 변화 때문이 다. Conventional cooking 가열처리 시 콩나물의 배축 조직감이 가열시간에 따라 증가하는 경향은 콩나물의 자엽보다 배축에 상 대적으로 더 많은 starch를 함유하고 있으며 sous-vide 방법과 달리 콩나물 주위에 물이 존재하므로 호화에 의한 결과이다[13]. Sous-vide 가열처리 방법에 의한 배축의 조직감은 자엽의 조직 감과 동일하게 가열시간 20 분까지 조직감이 증가된 상태로 유 지된 후 가열시간 30 분부터 감소하는 패턴을 나타내었으며, sous-vide 가열처리한 콩나물의 자엽 보다 수부함량이 더 많은 배축에서 더 높은 true stress를 나타내었다. Sous-vide 가열처리 시간에 따른 콩나물의 자엽의 조직감은 가열시간 $20 \mathrm{~min}$ 까지 생 콩나물의 조직감 보다 유의미하게 증가하여 유지되었으나, 가열시간 $30 \mathrm{~min}$ 에서 true stress가 감소하는 것은 가열에 의하 
Table 2 Sensory properties soybean sprout according heating method

\begin{tabular}{lcccc}
\multicolumn{1}{c}{ Samples } & Taste & Odor & Color & Texture \\
\hline Conventional cooking & $3.67 \pm 0.58$ & $3.67 \pm 1.53$ & $5.67 \pm 0.58$ & $5.17 \pm 0.29 *$ \\
Sous-vide & $4.33 \pm 1.15$ & $6.17 \pm 0.76$ & $4.00 \pm 1.00$ & $5.33 \pm 0.58$ \\
\hline
\end{tabular}

*Value with different superscripts within a column are significantly different at $p<0.05$. Each panel marked a response on a 7-point rating

여 파괴된 세포막으로 팽압의 손실 때문이다[20]. 이와 같이 팽 압 손실로 인한 true stress 감소는 콩나물의 자엽과 배축에서 모두 확인할 수 있다.

\section{콩나물의 미세구조}

생 콩나물과 conventional cooking 가열처리 후 동결 건조한 콩 나물의 미세구조를 전계방사형 주사전자현미경으로 관찰한 결 과는 Fig. 9에 나타난 바와 같이 콩나물 자엽의 공극의 간격은 가열방법에 따라 큰 차이를 보였다. Conventional cooking 가열 처리한 콩나물은 수분함량의 증가로 전분의 호화 작용이 일어 나 공극의 크기가 작아지고 치밀한 구조를 나타내었다. 팥의 경 우에도 가열하는 동안 부피가 증가하고 자엽에 부착되어 있는 펙틴이 열에 의하여 저하된다는 연구결과가 보고되었다[21]. 본 연구와 유사한 결과로, 채소류 중 붉은 양배추를 전통적인 데 치기 방법으로 가열처리 하였을 때 미세구조 관찰 시 세포와 세포 사이의 공간이 감소하는 것은 세포막의 파괴로 인한 것이 라 보고하였다[22].

\section{관능검사}

생 콩나물, conventional cooking과 sous-vide 가열처리한 콩나 물의 관능검사를 실시하였다. 관능검사 결과(Table 2)에서 맛, 향, 색, 전체적인 기호도는 가열처리 방법에 따라 유의미한 차 이를 나타내지 않았다. 콩나물은 자엽이 녹색을 띄지 않는 노 란색이어야 하며 배축은 유백색으로 맑아야 하고, 조리하였을 때 고소하고 너무 질기지 않아야 좋은 품질의 콩나물이라고 여 겨져 왔다[23]. Sous-vide 가열 처리한 콩나물은 conventional cooking한 콩나물에 비해 고소한 향과 맛이 높은 점수를 보였 으며, 전체적인 기호도는 수분함량 감소로 인한 콩나물 줄기의 외형이 conventional cooking한 콩나물보다 낮은 점수를 부여 받았지만, 유의미한 차이는 나타내지 않았다. Conventional cooking 가열처리한 콩나물의 배축은 sous-vide 가열방법에 의 한 콩나물에 비해 유백색이 더 맑아 높은 점수를 받았으며 조 직감은 기계적 측정과 동일하게 단단한 정도가 관능적으로 평 가되어 높은 점수를 받았다. 전체적인 기호도 역시 conventional cooking을 통한 시료가 높은 점수를 받았으며, 관능평가 결과와 조직감 측정 결과가 양의 상관관계를 보여줌을 알 수 있었다. 본 연구를 통하여 도출 된 형상이 일정하지 않은 콩나물 시료 의 조직감 측정방법은 가열처리 후 콩나물의 품질에 중요한 영 향을 주는 콩나물의 조직감의 측정에 적합한 방법으로 사료된다.

\section{초 록}

본 연구에서는 형상이 일정하지 않은 콩나물의 조직감 측정 방 법을 도출하고 가열처리 방법 및 시간에 따른 콩나물의 물리적
품질인자를 분석하였다. 조직감 측정을 위하여 실린더와 칼날형 프로브를 이용하여 deformation 시 프로브와 샘플이 접촉하는 면적의 고려 유무에 따라 표준편차가 적은 측정법을 평가하였 다. 앞서 도출된 조직감 측정 방법으로 콩나물을 conventional cooking, sous-vide 방법을 이용하여 콩나물을 $0,10,20,30$ $\min$ 가열 하였을 때의 물리적 품질특성을 비교하였다. 콩나물 의 자엽은 조직감 측정 축 방향에 따라 유의미한 차이가 없었 으며 $(p<0.05)$, 칼날형 프로브를 이용하여 프로브의 칼날과 콩나 물의 장축이 수평인 방향으로 조직감을 측정하여, 프로브와 샘 플이 $30 \%$ deformation시 접촉하는 면적을 고려한 true stress를 측정하는 것이 표준편차가 작았다. 콩나물의 배축은 프로브와 샘플이 접촉하는 면적을 고려한 조직감 측정법을 이용하여 실 린더와 칼날형 프로브로 측정 시 모두 유의미한 차이를 보였다. 또한, 가열처리 방법에 따른 조직감 측정 결과와 관능평가 결 과 사이에는 상관관계가 있었으며, 콩나물은 conventional cooking 방법으로 가열하는 것이 관능평가에서 더 높은 점수를 얻었다.

Keywords 경도 - 수비드 · 전통적인 조리 · 진응력 · 콩나물

감사의 글 본 성과물은 농촌진흥청 연구사업(세부과제번호: PJ012544022018) 의 지원에 의해 이루어진 것임.

\section{References}

1. Kim SY, Lee K, Yun HT, Kim JT, Kim UH, Kim YH (2011) Analyses of fatty acids and dietary fiber in soy sprouts. Korean J Crop Sci 56: 29-34

2. Lee J, Hwang YS, Lee JD, Chang WS, Choung MG (2013) Metabolic alterations of lutein, $\beta$-carotene and chlorophyll a during germination of two soybean sprout varieties. Food chem 141: 3177-3182

3. Cho SY, Lee YN, Park HJ (2009) Optimization of ethanol extraction and further purification of isoflavones from soybean sprout cotyledon. Food chem 117: 312-317

4. Lee KI, Hwang YJ, Ban HJ, Lim SJ, Jin HJ, Lee HS (2015) Impact of the growth of single-person households on the food market and policy tasks. Naju: Korea Rural Economic Institute, Naju

5. Matser AM, Krebbers B, van den Berg RW, Bartels PV (2004) Advantages of high pressure sterilisation on quality of food products. Trends Food Sci Technol 15: 79-85

6. Oey I, Lille M, Van Loey A, Hendrickx M (2008) Effect of highpressure processing on colour, texture and flavour of fruit-and vegetablebased food products: a review. Trends Food Sci Technol 19: 320-328

7. Kim SH, Kwon SM (2007) The study on selection attributes and expenditures according to the HMR (home meal replacement) customers' lifestyle. J Hosp Manage Tourism 25: 16-30

8. Lee KA, Kim YH, Kim HS (2016) Proximate compositions and sensory attributes of soybean sprouts with recommended soybean cultivars. J East Asian Soc Diet Life 26: 325-333

9. Lee CU, Yoon WB (2017) Sea Cucumber (Stichopus japonicus) Grading 
System Based on Morphological Features during Rehydration Process. J Korean Soc Food Sci Nutr 46: 374-380

10. Jin SK, Park JH, Shin D (2013) Effects of spent layer crushed breast addition on the quality of the cremi during storage. Korean J Food Sci Anim Resour 33: 251-257

11. Sun SH, Ki, SJ, Kim GC, Kim HR, Yoon KS (2011) Changes in quality characteristics of fresh-cut produce during refrigerated storage. Korean J Food Sci Technol 43: 495-503

12. Spencer M (1973) Chemical changes during cooking, processing and storage of food. J Nutr Food Sci 73: 11-14

13. Labaneiah MEO, Luh BS (1981) Changes of starch, crude fiber, and oligosaccharides in germinating dry beans. Cereal Chem 58: 135-138

14. Tian MS, Islam T, Stevenson DG, Irving DE (1997) Color, ethylene production, respiration, and compositional changes in broccoli dipped in hot water. J Am Soc Hortic Sci 122: 112-116

15. Sadik S, Ozbun JL (1968) The association of carbohydrate changes in the shoot tip of cauliflower with flowering. Plant Physiol 43: 1696-1698

16. dos Reis LCR, de Oliveira VR, Hagen MEK, Jablonski A, Flôres SH, de Oliveira Rios A (2015) Carotenoids, flavonoids, chlorophylls, phenolic compounds and antioxidant activity in fresh and cooked broccoli (Brassica oleracea var. Avenger) and cauliflower (Brassica oleracea var. Alphina F1). Food Sci Technol 63: 177-183
17. Park WK, Kim SH (1991) Quantitative analysis and physical properties of dietary fiber in vegetables. Korean Society of Food and Nutrition (Korea Republic)

18. Chang CY, Tsai YR, Chang WH (1993) Models for the interactions between pectin molecules and other cell-wall constituents in vegetable tissues. Food chem 48: 145-157

19. Kamchan A, Puwastien P, Sirichakwal PP, Kongkachuichai R (2004) In vitro calcium bioavailability of vegetables, legumes and seeds. J Food Compost Anal 17: 311-320

20. Van Buggenhout, S, Sila DN, Duvetter T, Van Loey A, Hendrickx M (2009) Pectins in processed fruits and vegetables: Part III-Texture engineering. Compr Rev Food Sci Food Saf 8: 105-117

21. Hsieh HM, Swanson BG, Lumpkin TA (1999) Starch gelatinization and microstructure of azuki an granules prepared from whole, abraded, or ground beans. Food Sci Technol 32: 469-480

22. Iborra-Bernad C, Tárrega A, García-Segovia P, Martínez-Monzó J (2014) Advantages of sous-vide cooked red cabbage: structural, nutritional and sensory aspects. Food Sci Technol 56: 451-460

23. Shon HK, Kim YH, Lee K (2014) Quality characteristics of bean sprouts with different Namulkong cultivars. Korean J Food Cook Sci 30: 340350 